\title{
Výstavba Vranovské a Brněnské přehrady a vodního díla Nové Mlýny a zánik obcí Bítov, Kníničky a Mušov
}

\section{EMIL KORDIOVSKÝ}

Klíčová slova: povodně - elektrifikace - zavlažování - rekreace - Bítov - Kníničky - Mušov - Pohořelice - Pasohlávky - Mikulov

\section{SOUHRN}

Stále vzrůstající počet povodní na dolních tocích Dyje a Svratky vyvolával potřebu úprav jejich toků. Ve 20. stol. se jevila proto potřeba výstavby přehrad. Krajina umožňovala jejich výstavbu nedaleko Vranova na Dyji a Kníniček na Svratce. Zdejší situaci ale nejvíce ovlivnila poválečná elektrifikace země. Zákon č. 438/1919 o státní podpoře při zahájení soustavné elektrizace z 22. července 1919 přinesl vedle potřebné elektrifikace zánik obcí Bítova a Kníniček, na jejichž katastrech měly být přehrady s elektrárnami postaveny. Současně se stavbou Vranovské přehrady měla být vybudována nová „vzorová" obec Bítov. Celá obec zcela zmizela ve vodách přehrady mezi únorem 1934 a dubnem 1935.

$\checkmark$ roce 1936 začala výstavba Brněnské přehrady. $V$ té době čítaly Kníničky 108 domů, ve kterých žilo 530 lidí. K dobudování přehrady došlo v roce 1940. Také v tomto prípadě bylo rozhodnuto o výstavbě nové obce.

Protože obě přehrady nedokázaly povodním zabránit, bylo $\vee 60$. letech 20. stol. rozhodnuto o výstavbě dalšího vodního díla Nové Mlýny, které mělo vyloučit záplavy na dolním toku Dyje a zajistit závlahy na výměře 35 až 40 tis. ha zemědělské půdy. Stavba byla rozdělena na dvě etapy a při výstavbě zdrže první stavby bylo počítáno se zlikvidováním celé obce Mušov. V prípadě Mušova byla obyvatelům nabídnuta možnost výstavby $v$ sousedních Pasohlávkách, Pohořelicích a Mikulově. Městečko zaniklo v letech 1977-1980.

\section{ÚVOD}

Po změnách, které postihly monarchii v polovině 19. století, se vývoj ve všech třech lokalitách odvíjel v podstatě stejně. Nejdůležitější změnou byl zánik patrimoniální správy, vykoupení z roboty a vznik samosprávných obecních úradů, do nichž si svobodní občané volili zastupitele, kteři řídili společné zájmy svých obcí. Po období relativního klidu po skončení prusko-rakouské války všechny tři obce byly postiženy válečnými událostmi z tzv. Velké Války (1914-1918) ukončené rozpadem monarchie a vznikem Československé republiky. Na rozdíl od Mušova, který byl osídlen převážně německy mluvícím a monarchisticky cítícím obyvatelstvem, konec války, rozpad Rakousko-uherska a vznik Československé republiky lidé v Bítově a Kníničkách vítali.

Poválečný rozvoj republiky přinášel do obcí nové možnosti obživy. Obyvatelé všech tří obcí se zabývali jako hlavním zdrojem obživy zemědělstvím, i když například v Bítově hrálo větší roli pěstování dobytka, nebot zde díky prírodním poměrům vládl nedostatek vhodné půdy pro rostlinnou výrobu na rozdíl od poměrů v Kníničkách a hlavně v Mušově, kde pěstování obilí a řepy mělo větší význam než chov dobytka. V prípadě Bítova se začal rozvíjet i turistický ruch, nebot kouzelná krajina v okolí městečka lákala bohatší vrstvy tehdejší společnosti k letní rekreaci, která dávala místním obyvatelům přiležitost k uplatnění svých zemědělských produktů při zásobování a ubytování rekreantů. V př́padě Kníniček zase kladně působila možnost obživy při zásobování Brna a poskytování pracovních př́ležitostí v brněnských továrnách. Všechny tři katastry však trpěly stále četnějšími povodněmi snad s výjimkou zimy po zbytek celého roku [1-5]. Ty nakonec ve všech třech případech sehrály jednu z hlavní rolí při jejich zániku.

\section{VÝSTAVBA PŘEHRAD}

Osud Bítova a Kníniček nejvíce ovlivnila poválečná elektrifikace země. Zákon č. 438/1919 o státní podpoře při zahájení soustavné elektrizace, který byl vyhlášen 22. července 1919, znamenal významný krok v elektrifikaci celé země. Jeho provádění přineslo zánik obcí, na jejichž katastrech měly být postaveny préehrady s elektrárnami, při čemž obě lokality a část jejich katastrů měly zmizet pod vodní hladinou. Co se Bítova týče, začalo se uvažovat o výstavbě prèhrady na řece Dyji již před první světovou válkou [6]. Válka a období poválečné rekonstrukce nově vzniklé republiky tyto úvahy na čas zastavily. Na pořad dne se plány na výstavbu opět obnovily pod tlakem zvýšené povodňové situace $\checkmark$ celém dolním dyjském a svrateckém povodí (obr. 1).

ZME získaly koncesi na stavbu přehrady na Dyji nedaleko Bítova v roce 1921. Městečku byla už v roce 1912 vydána stavební uzávěra [7]. Zákaz staveb byl Moravským zemským výborem obnoven 9. 2. 1924. Současně se stavbou přehrady měla být vybudována nová "Vzorová" obec Bítov, pro kterou po složitých jednáních s majitelem pozemků bítovského velkostatku Jiřím HaasHaasenfelsem a okolními obcemi byla vybrána poloha "Vranč". Moravský zemský výbor o vyvlastnění potřebných pozemků patřících velkostatku rozhodl 10. 4. 1926 [7-11].

Stavební práce byly zahájeny v prvém květnovém týdnu 1932 a první občan se do nové obce nastěhoval 3. 1. 1933. Celá obec zcela zmizela ve vodách přehrady mezi únorem 1934 a dubnem 1935 [12]. 


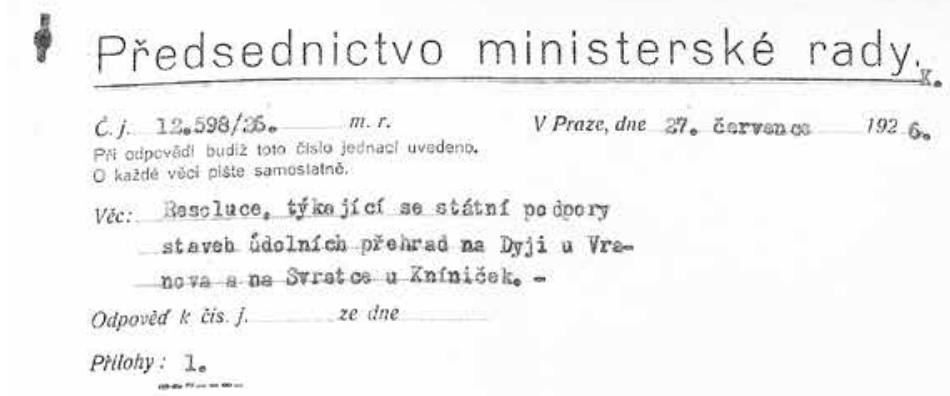

¿inisterstvu

$$
\text { veřejnýcł praç }
$$

$$
\therefore \quad P \quad x+20 .
$$

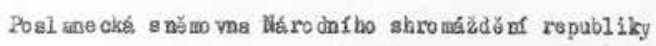

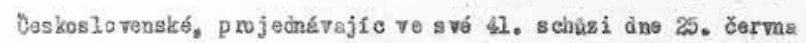
1926 osncvu sákona o finančm podpo re elekt rísace venkova, príjo1a resoluci, tóks jies se státas podpory steveb údolnf di prohred na Dyji u Vrazo va a na Svrateo u Zníničck.

Reso luci tu gas láme ministerst nia: financr, verejnjoh

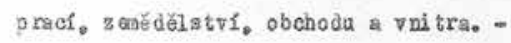

$$
\text { Za predsodu vlády : }
$$

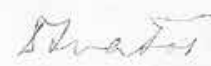

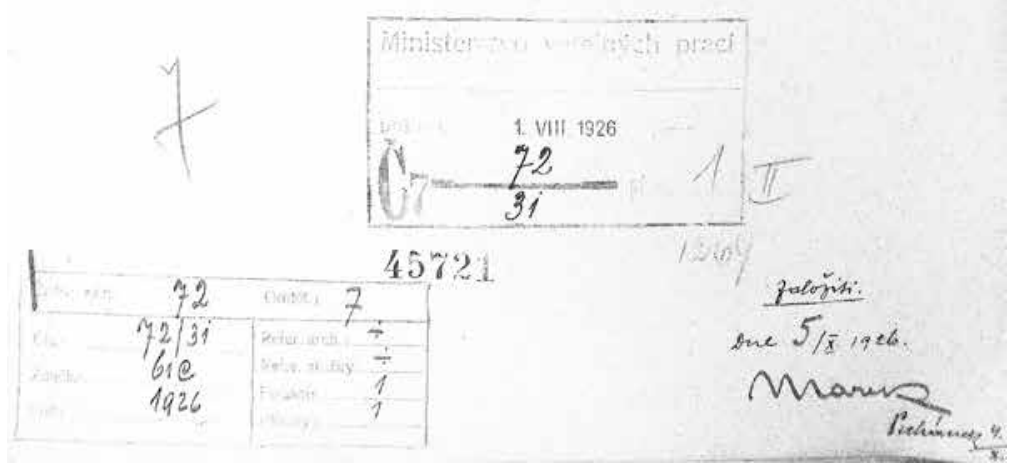

Obr. 1. Rezoluce Předsednictva ministerské rady na podporu staveb údolních přehrad na Dyji a Svratce v roce 1926 (NA Praha, MVP, kar. 190)

Fig. 1. Resolution of the Presidency of the Council of Ministers on the support of the Dyje and Svratka Dams in 1926

První úvahy o výstavbě přehrady na řece Svratce nad Brnem se objevily již $\checkmark$ roce 1872. V roce 1911 bylo provedeno zaměření uvažované zátopové oblasti a v r. 1924 byl vypracován první projekt výstavby přehrady [13]. Vedle zabránění ničivým povodním se objevuje velmi důležitý problém zásobování města Brna pitnou a užitkovou vodou. Pro novou obec Kníničky bylo vybráno místo na zbytkových statcích katastrů Bystrce, Prštic, Ostrovačic a Říčan [14, 15]. V roce 1936 začala výstavba přehrady. $\vee$ té době čítala obec 108 domů, ve kterých žilo 530 lidí [16]. K dobudování přehrady došlo v roce 1940 (obr. 2).

Staré městečko Mušov leželo v jihomoravské oblasti osídlené převážně německým obyvatelstvem. Při posledním předválečném sčitání lidu v roce 1930 zde bylo napočítáno 667 Němců a 38 Čechů [17].

Povodně ve druhé půlce 19. a ve 20. století se zde stávaly stále častějšími. Řešení záplav na řece Dyji bylo předmětem různých úvah již v 19. století, avšak
11

\section{MORAVSKÝ ZEMSKÝ VÝBOR.}

\author{
Cis. 62.799/26. \\ Budis pri oupovísi uvedeno \\ $V$ BRNĚ. dne 17.prosinoe 1926. \\ Jaoln1 priehrada u Knin1Cek, odevzdan1 \\ zbytko vych statkl moravsizbna zemsize- \\ pozemky za brane pro stavbu údoln \\ prady.- \\ Opis.-
}

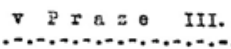

Valătynskd 134 .

\begin{abstract}
$\checkmark$ purištich letech má se uskutečn1ti no fece Srratce,

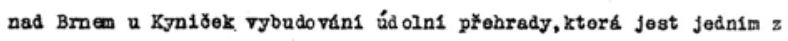

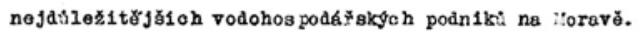

Pokud se týce této stavby jest poznanenati toto :

Kedostatek rody $\nabla$ řeac Svratce $\nabla$ dob̆̀ suchs púsobi

mĕ: tu Brnu velké neạnáse, nahledĕ ani $k$ tomu, že podminúje znaŏné zmenše

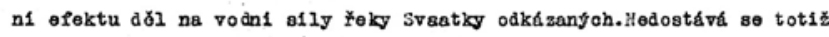

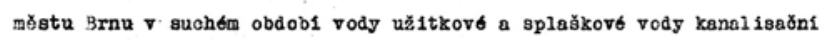
otravuj1 vodu $v$ řece tak, že zdrav1 obyvatel stva jok v 3rnĕ,tak zejméne $v$ obcich ležlo1oh pod Brnem je ve znache miře ohrożeno.llaproti tomu nadbytek vody ve svratce ss povodnĕ zpưsobuje zátopy zv1ás̆tĕ pod Brnem od Židlochovio až $k$ jejimu ústí do Dyjo a Ivaně.V̌̃em tĕnto no-

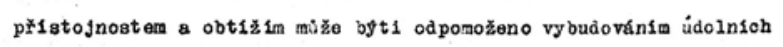

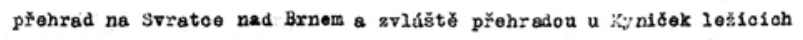
$\mathrm{v}$ bezprostředn1 blizkosti Brna. Přehrada tato umožnila by nad to za-

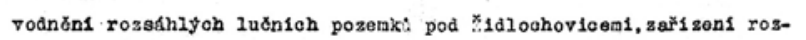

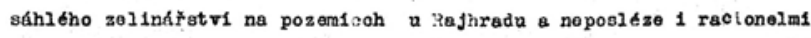

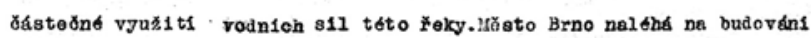
$\cdot ; \cdot$

Obr. 2. Informace Moravského zemského výboru o nutnosti výstavby přehrady u Kníniček v roce 1926 (NA Praha, MVP, kar. 190)

Fig. 2. Information from the Moravian Regional Committee on the need to build a dam at Kníničky in 1926

naráželo na nechut̉ majitelů pozemkư na čele s lichtenštejnskou správou vzdát se zemědělské půdy nebo lesních porostů. Stále se zvyšující četnost a velikost záplav po scelování půdy a jejím nevhodném obhospodařování JZD ve druhé polovině 20. století Vranovská a Brněnská přehrada povodním zabránit nedokázaly. Proto na základě jednání tehdejších krajských stranických a státních orgánů v roce 1960 v rámci vypracování komplexního plánu vodohospodářské investiční výstavby v kraji měla být situace řešena výstavbou nádrže u Nových Mlýnů. Vyřešení odtokových poměrů na jižní Moravě bylo uloženo usnesením vlády č. 826/1959, na jehož podkladě byla zpracována Výhledová studie úprav řeky Moravy a Dyje v oblasti jižní Moravy z r. 1962. Po celá 60. léta pak probíhala různá jednání, která vedla k projektovému řešení vodních nádrží, známých jako vodní dílo Nové Mlýny, pod jehož hladinou mělo zmizet starodávné městečko Mušov [18] (obr. 3).

Projektové řešení vypracovala brněnská pobočka Hydroprojektu v roce 1965. Toto řešení bylo schváleno Ministerstvem zemědělství, lesního a vodního hospodářství 18. 9. 1969, které doporučilo rozdělit celé vodní dílo na dvě etapy. V první etapě měla být zřizena první a druhá zdrž s př́slušnými stavbami, v níž měl být 


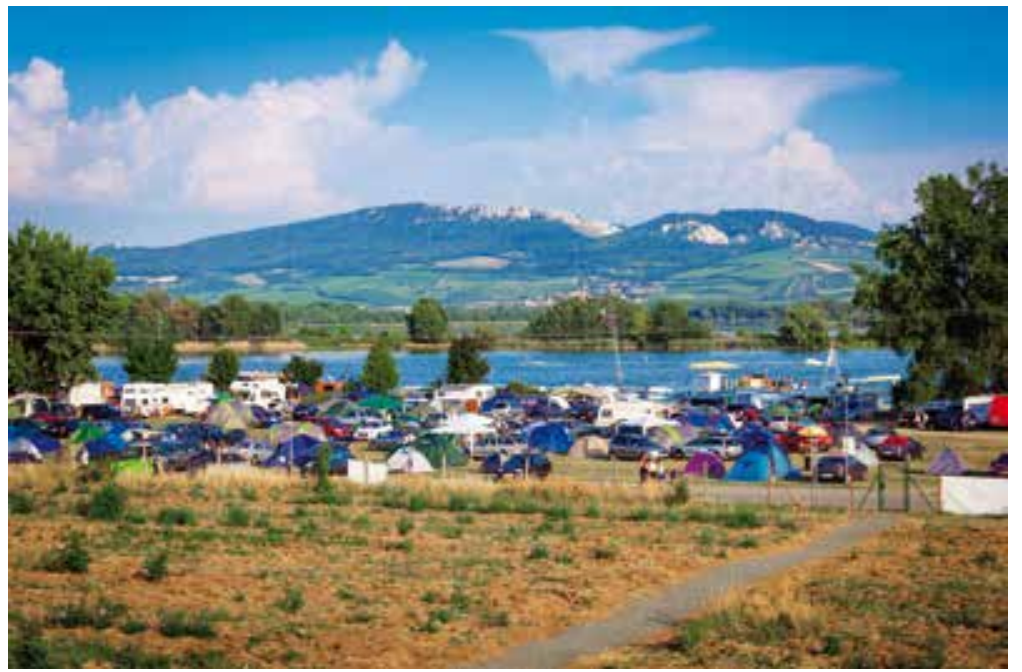

Obr. 3. Autokemp Rekreačního střediska Merkur Pasohlávky (2016)

Fig. 3. Holiday Resort Merkur Pasohlávky car camping (2016)

zlikvidován i Mušov, a v druhé etapě měla být zhotovena zdrž třetí u Nových Mlýnů. První etapa byla plánována na léta 1974-1979. Přímým investorem mělo být Povodí Moravy v Brně, generální dodavatel stavební části Ingstav, n. p. Brno, technologické části ČKD Blansko a Sigma, n. p. Lutín. ONV Břeclav a ONV Znojmo na to vydaly v r. 1966 celkem devět dílčích územních rozhodnutí [19].

Ve zdůvodnění stavby bylo uvedeno, že účelem nádrží je snížení kulminace povodní na Dyji, vyloučení záplav pod přehradou a zajištění závlah na výměře 35 až 40 tis. ha zemědělské půdy včetně nadlepšení průtokových poměrư v řece Dyji. Mimo jiné měla být přehradou omezena i pravidelná komáří kalamita v celém dyjském údolí.

Při výstavbě druhé zdrže první stavby bylo počítáno se zlikvidováním celé obce Mušov se 113 rodinnými domy o 152 bytech. Na rozdíl od výstavby nového Bítova a nových Kníniček $v$ prípadě Mušova nebylo uvažováno o výstavbě nové vesnice. Obyvatelům byla nabídnuta možnost usazení v sousedních Pasohlávkách, Pohořelicích a Mikulově [20]. Při projektování první nádrže bylo uvažováno i o jejím rekreačním využití. To časem dalo vzniknout rozsáhlému rekreačnímu středisku a autokempu s názvem Merkur Pasohlávky s hřišti a možností koupání a vodních sportů v rekreačním zařízení Laguna Pasohlávky [21].

\section{Literatura}

[1] Státní okresní archiv Znojmo: AM 16 - Archiv městečka Bítov, (1777) 1850-1945 (1975).

[2] Archiv města Brna: A 34 - Obec Kníničky 1855-1945 (1951).

[3] Státní okresní archiv Břeclav se sídlem v Mikulově: NAD 184 - MNV Mušov 1945- 1976 (1978).

[4] SOkA Mikulov, NAD 202 - MNV Rakvice, Obecní kronika, s. 124-125.

[5] BRÁZDIL, R. a kol. Povodně v Brně. Historie povodní, jejich př́činy a dopady. Brno, 2010.

[6] WOLFSCHÜTZ, J. Die Projektsidee Sperre Vöttau (Meixner) vom hydrotechnischen Standpunkte [Projekt přehrady u Bítova z hlediska hydrotechnického.]. Mitteilungen des Mitteilungen des Deutschen Ingenieur-Vereines in Mähren, 1913, 6, s. 37-42.

[7] STARÁ, J. Architektura nového Bítova. In: Sborník Státního okresního archivu Znojmo 2007, Znojmo 2008, s. 22-23.

[8] SOkA Znojmo: AM 16, archiv městečka Bítova, kar. 3.

[9] STARÁ, J. Architektura nového Bítova, s. 24.

[10] SOkA Znojmo: AM 16, kar. 6.

[11] Národní archiv Praha: fond Ministerstvo veřejných prací, kar. 190

[12] SOkA Znojmo: AM 16, Obecní kronika, s. 142 an.

[13] BAŽANT, J. Ke stavbě prehrady u Kníniček. Lidové noviny 12. 3. 1935

[14] 5 SOkA Znojmo: AM 16, archiv městečka Bítova, kn. 3.
[15] NA Praha: fond Ministerstvo veřejných prací, kar. 190.

[16] Retrospektívní lexikon obcí Československé socialistické republiky 1850-1970. Federální statistický úrad Praha 1978, I. sV.

[17] BARTOŠ, J., SCHULZ, J., TRAPL, M. Historický mistopis Moravy a Slezska v letech 1848-1960, (okresy Znojmo, Moravský Krumlov, Hustopeče, Mikulov), IX. sv., Ostrava 1984.

[18] Moravský zemský archiv Brno, B124-III. manipulace - KNV Brno (1808) 1945-1960, kar. 27.

[19] MZA, B 338 - JmKNV Brno - 1960-1990 (1991), kar. 663.

[20] Rovnost, 8. 1. 1977.

[21] Dostupné z: http://www.kemp-merkur.cz/ (staženo 20. 5. 2016).

\section{Autor}

PhDr. Emil Kordiovský

凶emil.kordiovsky@seznam.cz

Státní okresní archiv Břeclav se sídlem v Mikulově

Přispěvek prošel lektorským řizením.

\section{CONSTRUCTION OF THE VRANOV AND BRNO DAM AND THE SYSTEM OF WATER RESERVOIRS OF NOVÉ MLÝNY AND THE DEMISE OF BÍTOV, KNÍNIČKY AND MUŠOV}

\section{KORDIOVSKY, E.}

State District Archive in Břeclav based in Mikulov

Keywords: floods - electrification - irrigation - recreation - Bítov Kníničky - Mušov - Pohořelice - Pasohlávky - Mikulov

The ever-increasing number of floods in the lower reaches of the Dyje and Svratka caused the need to adjust their flows. In the $20^{\text {th }}$ century was the need for dams to be built. The landscape allowed their construction near Vranov at Dyje and Kníničky at Svratka. But the situation in the country was most affected by the post-war electrification of the country. Law No. 438/1919 on state aid for the commencement of systematic electrification on July 22, 1919 brought, besides the necessary electrification, the demise of the villages of Bitov and Kníniček, on whose cadastres the dams with the power stations were to be built. At the same time, a new "model" village of Bítov was built with the construction of the Vranov Dam. The whole village completely disappeared in the waters of the dam between February 1934 and April 1935.

In 1936 the construction of the Brno Dam began. At that time, Kníničky had 108 houses, inhabited by 530 people. The completion of the dam was in 1940. Also in this case, it was decided to build a new municipality.

Because both water reservoirs failed to prevent flooding, in the 60's it was decided to build system of water reservoirs of Nové Mlýny, which should eliminate flooding in the lower reaches of the Dyje River and provide irrigation to an area of 35 to 40 thousand ha of agricultural land. The construction was divided into two stages and during the construction of the first building, it was planned to destroy the entire village of Mušov. In the case of Mušov, the inhabitants were offered the possibility of construction in neighboring Pasohlávky, Pohořelice and Mikulov. The town disappeared in 1977-1980. 